\title{
RANCANG BANGUN SISTEM INFORMASI INDEKS KEPUASAN MASYARAKAT TERHADAP PELAYANAN ADMINISTRASI TERPADU KECAMATAN BERBASIS WEB (STUDI KASUS: KANTOR KECAMATAN RAJEG)
}

\author{
Diyah Ayuni Magfiroh ${ }^{1}$, Ali Firdaus ${ }^{2}$, Agung Wibowo ${ }^{3}$, Desi Nurnaningsih ${ }^{4}$ \\ 1,2,3,4 Program Studi Teknik Informatika, Fakultas Teknik, Universitas Muhammadiyah Tangerang \\ Jl. Perintis Kemerdekaan 1/33 Cikokol Kota Tangerang \\ Co Responden Email: agung@ft-umt.ac.id
}

Article history

Received Nov 17, 2020

Revised Jan 15, 2021

Accepted Jan 30, 2021

Available online Feb 05, 2021

Keywords

Information System,

IKM,

PATEN,

PIECES,

$U M L$

\begin{abstract}
In the current era of globalization, one of the big challenges that are entered by the government, especially the government is how to create a professional apparatus, has a high work ethic, competitive advantage, and the ability to uphold bureaucratic ethics in carrying out its duties and functions and fulfilling the aspirations of society. This study aims to build a web-based public satisfaction index (IKM) information system. The design of information systems uses the System Development Life Cycle (SDLC) system development stage with the Waterfall model. The system analysis technique uses the PIECES method (Performance, Information, Economy, Control, Efficiency and Service) and the system drawing stage uses an object-oriented analysis approach with UML (Unified Model Language). The system developed is web-based using the PHP programming language. This web-based community satisfaction index (IKM) information system application can help calculate community satisfaction index data which will become foodstuffs for services provided by sub-district integrated administration services (PATEN).
\end{abstract}

\section{Abstrak}

Dalam era globalisasi saat ini salah satu tantangan besar yang dihadapi oleh pemerintah khususnya pemerintah daerah adalah bagaimana mewujudkan aparatur yang profesional, memiliki etos kerja yang tinggi, keunggulan kompetitif, dan kemampuan memegang teguh etika birokrasi dalam menjalankan tugas dan fungsinya dan memenuhi aspirasi masyarakat. Penelitian ini bertujuan untuk membangun sistem informasi indeks kepuasan masyarakat (IKM) berbasis web. Perancangan sistem informasi ini menggunakan tahap pengembangan sistem System Development Life Cycle (SDLC) dengan model Waterfall. Teknik analisis sistem dengan metode PIECES (Performance, Information, Economy, Control, Eficiency and Service) dan tahap penggambaran sistem menggunakan pendekatan analisis berorientasi objek dengan UML (Unified Model Languange). Sistem yang dikembangkan berbasis web dengan menggunakan bahasa pemrograman PHP. Aplikasi sistem informasi indeks kepuasan masyarakat (IKM) berbasis web ini dapat membantu mempermudah perhitungan data indeks kepuasan masyarakat yang akan menjadi bahan penilaian terhadap unsur pelayanan terutama pelayanan administrasi terpadu kecamatan (PATEN).

\section{PENDAHULUAN}

Dalam era globalisasi saat ini salah satu tantangan besar yang dihadapi oleh pemerintah khususnya pemerintah daerah adalah bagaimana mewujudkan aparatur yang profesional, memiliki etos kerja yang tinggi, keunggulan kompetitif, dan kemampuan memegang teguh etika birokrasi dalam menjalankan tugas dan fungsinya dan memenuhi aspirasi masyarakat.

Tantangan tersebut merupakan hal yang beralasan mengingat secara empiris masyarakat di daerah menginginkan agar aparat pemerintah 
dalam menjalankan tugas-tugasnya dapat bekerja secara maksimal yang akhirnya dapat memberikan pelayanan yang terbaik bagi masyarakat. Untuk dapat menyelenggarakan pemerintahan yang baik dituntut aparatur pemerintah yang profesional, hal ini merupakan prasyarat dalam meningkatkan mutu penyelenggaraan dan kualitas pelayanan yang akan diberikan kepada masyarakat.

Salah satu harapan masyarakat selaku konsumen pelayanan adalah mengharapkan peningkatan pelayanan yang lebih baik dan cepat, sebagian masyarakat selalu mengeluh dan kecewa terhadap pelayanan yang diberikan. Pelayanan yang diberikan secara umum masih rendah dan belum memuaskan masyarakat, pelayanan yang diberikan terlalu berbelit-belit dengan berbagai alasan yang kurang dapat diterima oleh masyarakat, sehingga pelayanan yang diberikan masih dikatakan belum maksimal.

Salah satu upaya untuk meningkatkan kualitas pelayanan publik, sebagaimana diamanatkan dalam Undang-Undang Republik Indonesia Nomor 25 Tahun 2000 tentang Program Pembangunan Nasional (PROPENAS), perlu disusun indeks kepuasan masyarakat sebagai tolak ukur untuk menilai tingkat kualitas pelayanan. Di samping itu data indeks kepuasan masyarakat akan dapat menjadi bahan penilaian terhadap unsur pelayanan yang masih perlu perbaikan dan menjadi pendorong setiap unit penyelenggara pelayanan untuk meningkatkan kualitas pelayanannya (KEPMENPAN No. 25 Tahun 2004).

Selain itu, berdasarkan Peraturan Menteri Pendayagunaan Aparatur Negara dan Reformasi Birokrasi Republik Indonesia Nomor 16 Tahun 2014 tentang pedoman survei kepuasan masyarakat terhadap Penyelenggaraan Pelayanan Publik, pada Pasal 2 bahwa penyelenggara pelayanan publik wajib melakukan survei kepuasan masyarakat secara berkala minimal 1 (satu) kali setahun. Kemudian pada Pasal 5 dijelaskan bahwa penyelenggara pelayanan publik mempublikasikan hasil survei kepuasan masyarakat terhadap penyelenggaraan setiap jenis pelayanan publik dan metodologi survei yang digunakan, dan hasil survei kepuasan masyarakat dilaporkan kepada Menteri dalam Sistem Informasi Pelayanan Publik (SIPP).

Bertujuan untuk membangun sebuah sistem informasi yang dapat membantu upaya Kecamatan Rajeg untuk meningkatkan kualitas pelayanan publik dengan survei berbasis web yang memudahkan masyarakat untuk memberikan penilaian. Dengan latar belakang tersebut penulis ingin membuat suatu sistem informasi indeks kepuasan masyarakat terhadap pelayanan administrasi terpadu kecamatan berbasis web.

\section{Sistem Informasi}

\section{TINJAUAN PUSTAKA}

Sistem Informasi adalah mengumpulkan, memproses, menyimpan, menganalisis, dan menyebarluaskan informasi untuk tujuan tertentu. (Rainer dan Cegielski, 2011).

Sistem informasi merupakan sebuah kombinasi dari manusia, perangkat keras (hardware), perangkat lunak (software), jaringan komunikasi, sumber data, kebijakan, dan prosedur yang memiliki kemampuan untuk mengumpulkan, menyimpan, mengubah, dan menyebarluaskan informasi dari sebuah organisasi. (O’Brien dan Marakas, 2014).

\section{Indeks Kepuasan Masyarakat (IKM)}

Indeks Kepuasan Masyarakat (IKM) adalah tingkat kepuasan masyarakat dalam memperoleh pelayanan yang diperoleh dari penyelenggara atau pemberi pelayanan sesuai harapan dan kebutuhan masyarakat. (Keputusan Menteri Pendayagunaan Aparatur Negara (KEPMENPAN) Nomor 63 Tahun 2003 tentang Pedoman Umum Penyelenggaraan Pelayanan Publik).

Indeks Kepuasan Masyarakat (IKM) adalah data dan informasi tentang tingkat kepuasan masyarakat yang diperoleh dari hasil pengukuran secara kuantitatif dan kualitatif atas pendapat masyarakat dalam memperoleh 
pelayanan dari aparatur penyelenggara pelayanan publik dengan membandingkan antara harapan dan kebutuhannya. (Keputusan Menteri Pemberdayaan Aparatur Negara Nomor KEP25/M.PAN/2/2004).

Indeks Kepuasan Masyarakat adalah hasil pengukuran dari kegiatan survei kepuasan masyarakat berupa angka. Angka ditetapkan dengan skala 1 (satu) sampai dengan 4 (empat). (Peraturan Menteri Pendayagunaan Aparatur Negara Dan Reformasi Birokrasi Republik Indonesia Nomor 14 Tahun 2017).

\section{Pelayanan Administrasi Terpadu Kecamatan (PATEN)}

Pelayanan Administrasi Terpadu Kecamatan (PATEN) adalah penyelenggaraan pelayanan publik di kecamatan dari tahap permohonan sampai ketahap terbitnya dokumen dalam satu tempat. Ruang lingkup PATEN melingkupi pelayanan bidang perizinan dan pelayanan bidang non-perizinan. Maksud penyelenggaraan PATEN adalah mewujudkan kecamatan sebagai pusat pelayanan masyarakat dan menjadi simpul pelayanan bagi kantor/badan pelayanan terpadu di kabupaten/kota. (Peraturan Menteri Dalam Negeri Nomor 4 Tahun 2010).

\section{PIECES}

PIECES (Performance, Information, Economy, Control, Eficiency and Service) adalah metode analisis sebagai dasar untuk memperoleh pokok-pokok permasalahan yang lebih spesifik. Dalam menganalisis sebuah sistem, biasanya akan dilakukan terhadap beberapa aspek antara lain adalah kinerja, informasi, ekonomi, pengendalian/keamanan, efisiensi dan pelayanan pelanggan. Analisis ini disebut dengan PIECES Analysis. (Wukil Ragil, 2010).

\section{Unified Model Language (UML)}

Unified Model Language (UML) adalah bahasa standar yang digunakan untuk memvisualisasi, menspesifikasikan, membangun, dan mendokumentasikan artifak dari sistem perangkat lunak. (Alim, 2013).
Unified Model Language (UML) adalah salah satu standar bahasa yang banyak digunakan di dunia industri untuk mendefinisikan requirement, membuat analisis dan desain, serta menggambarkan arsitektur dalam pemrograman berorientasi objek. UML merupakan bahasa visual untuk pemodelan dan komunikasi mengenai sebuah sistem dengan menggunakan diagram dan teks-teks pendukung. (Rosa A.S dan M. Shalahudin, 2014).

\section{- Usecase Diagram}

Use case diagram adalah gambar dari beberapa atau seluruh aktor dan use case dengan tujuan mengenali interaksi mereka dalam suatu sistem. Use case diagram menggambarkan fungsionalitas yang diharapkan dari sebuah sistem, yang ditekankan adalah "apa" yang diperbuat sistem, dan bukan "bagaimana". (Yasin, 2012).

\section{- Activity Diagram}

Activity diagram merupakan diagram yang bersifat dinamis. Activity diagram adalah tipe khusus dari diagram state yang memperlihatkan aliran dari suatu aktifitas ke aktifitas lainnya dalam suatu sistem dan berfungsi untuk menganalisa proses. (Murad, 2013).

\section{- Sequence Diagram}

Sequence diagram dibuat berdasarkan activity diagram dan class diagram yang telah dibuat, maka digambarkan sequence diagram yang menggambarkan aliran pesan yang terjadi antar kelas dengan menggunakan operasi yang dimiliki kelas tersebut. (Wijayanto, 2013).

\section{- Class Diagram}

Class diagram dibuat berdasarkan use case diagram dan activity diagram. (Vidia, 2013). Class Diagram menggambarkan sistem dari segi pendefinisian kelas-kelas untuk membangun sistem. (Erna Astriyani, 2018). 


\section{METODE PENELITIAN}

\section{Jenis Penelitian}

Penelitian yang dilakukan merupakan sebuah penelitian terapan dengan menggunakan metode pengembangan sistem SDLC dan telah dijalan dengan terstruktur, penelitian ini menggunakan model pembangunan sistem Waterfall yang dikemukakan oleh Ian Sommerville.

\section{Populasi Dan Sampel}

Populasi dalam penelitian ini adalah seluruh masyarakat yang menjadi pelanggan di Kantor Kecamatan Rajeg. Besarnya populasi dalam penelitian dan mempertimbangkan faktor-faktor yang menunjang keberhasilan pelaksanaan penelitian maka dalam penelitian ini dilakukan sampling.

Teknik sampling yang digunakan dalam penelitian ini adalah teknik non-probability sampling dengan jenis accidental sampling, yaitu teknik penentuan sampel berdasarkan faktor spontanitas, artinya siapa saja yang secara tidak sengaja bertemu dengan peneliti dan sesuai dengan karakteristik atau ciri-cirinya yaitu masyarakat yang menjadi pelanggan Kantor Kecamatan Rajeg, maka orang tersebut dapat digunakan sebagai sampel (responden) sebagai dasar pengumpulan data.

Jumlah sampel ditentukan sebanyak 150 responden yakni dengan rumus $(14+1)$ x $10=$ 150 responden. Penetapan jumlah tersebut sesuai dengan Keputusan Menteri Pemberdayaan Aparatur Negara Nomor KEP25/M.PAN/2/2004.

\section{Teknik Pengumpulan Data}

Penelitian ini menggunakan sumber data yang diperoleh secara lisan dan tertulis. Teknik pengumpulan data yang digunakan dalam penelitian ini meliputi :

\section{- Observasi}

Observasi yang dimaksud adalah pengumpulan data dengan cara mengamati pelayanan yang diberikan kepada masyarakat. Observasi dilakukan dengan tujuan untuk mengetahui secara langsung tentang keadaan Kantor Kecamatan Rajeg, lingkungan Kantor Kecamatan Rajeg, fasilitas serta kegiatan pelayanan di Kantor Kecamatan Rajeg. Sehingga peneliti mendapatkan data yang akurat dan relevan dengan tujuan penelitian yang diharapkan.

\section{- Wawancara}

Wawancara dilakukan dengan cara mewawancarai langsung pihak-pihak terkait, yaitu bapak Endang Mulyawan, S.Sos., M.M. dengan jabatan Kasi Pelayanan yang berguna untuk mendapatkan informasi maupun data-data yang dibutuhkan untuk perancangan sistem yang akan dibangun.

\section{- Studi Pustaka}

Studi pustaka dilakukan dengan melakukan pencarian terhadap buku buku yang berhubungan dengan penelitian, karya-karya ilmiah maupun jurnal, baik yang terdapat diperpustakaan maupun yang terdapat di internet, yang dijadikan referensi dalam penyusunan penelitian ini sehingga data-data yang disajikan dapat dipertanggung jawabkan.

\section{- Angket atau Kuesioner}

Pada penelitian ini, angket atau kuesioner digunakan untuk mengambil data tentang tingkat kepuasan masyarakat sebagai pelanggan dari Pelayanan Kantor Kecamatan Rajeg. Jenis angket atau kuesioner yang digunakan adalah tertutup. Teknik ini dipilih karena memudahkan responden dalam memberikan jawaban dan dapat mempermudah peneliti dalam mengambil data.

\section{HASIL DAN PEMBAHASAN}

\section{Desain Penelitian}

Berikut ini desain diagram UML (Unified Modeling Language) yang dibuat dalam rangka mengembangkan model Waterfall sistem informasi indeks kepuasan masyarakat terhadap pelayanan administrasi terpadu kecamatan berbasis web. 


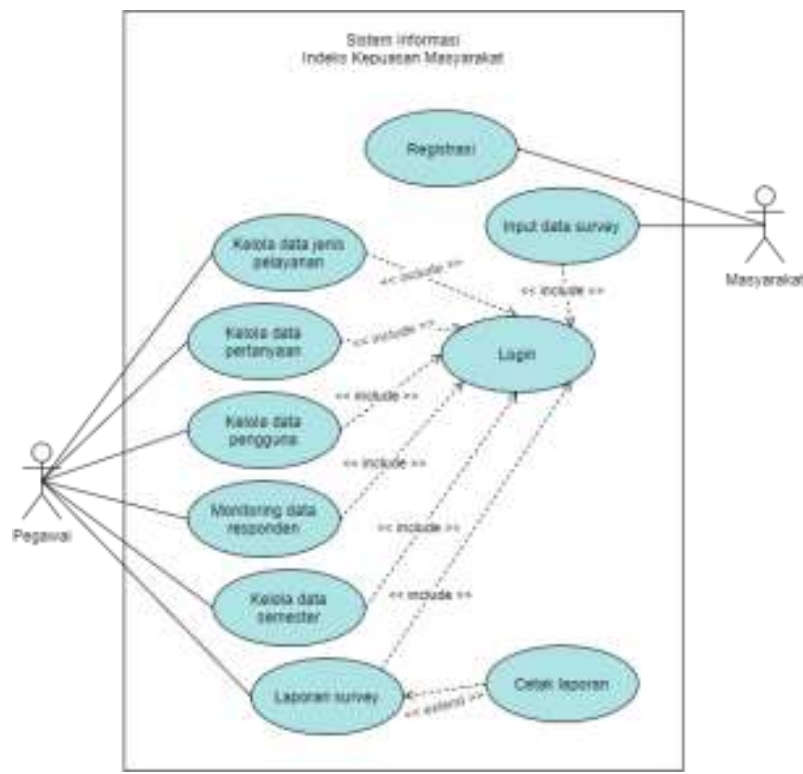

Gambar 1. Usecase Diagram

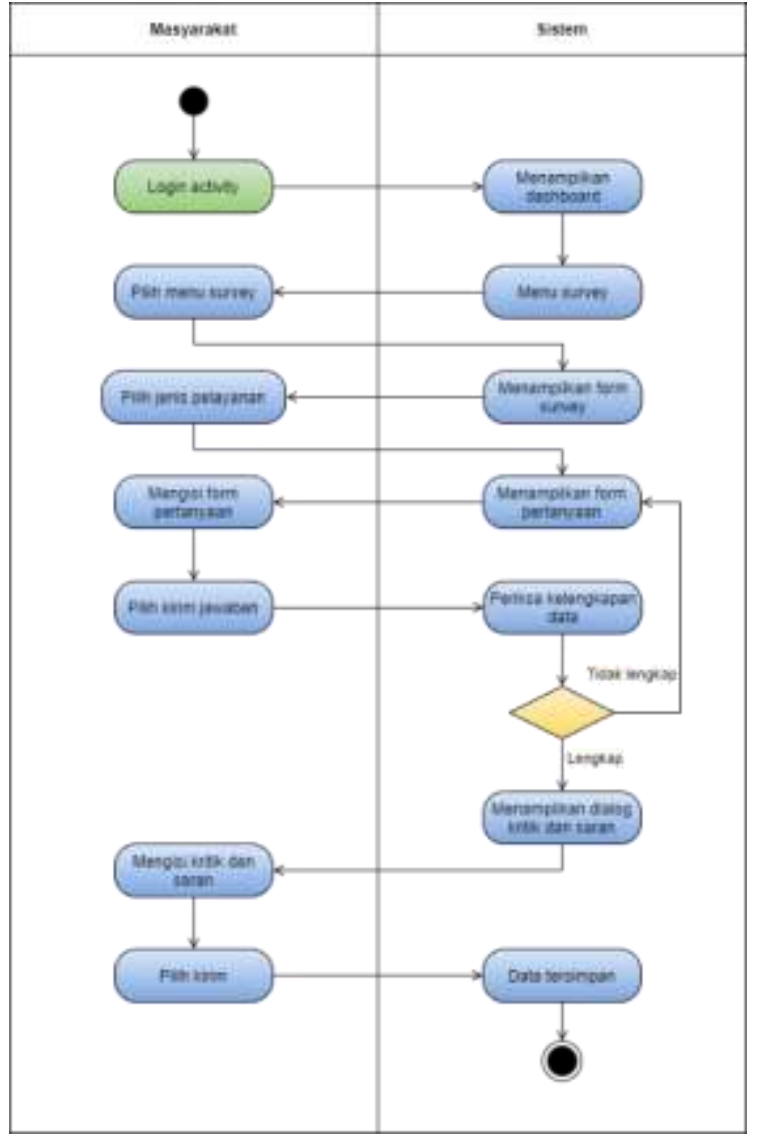

Gambar 2. Activity Diagram Input Data Survey

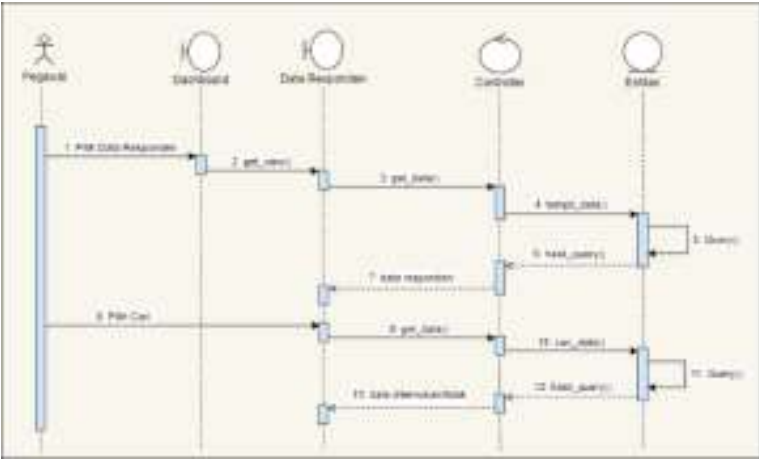

Gambar 3. Sequence Diagram Monitoring Data Responden

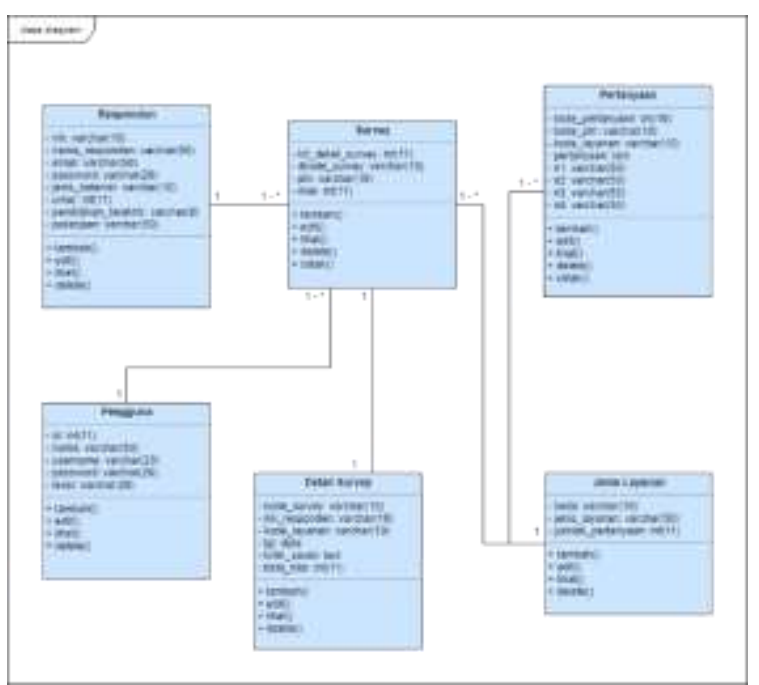

Gambar 4. Class Diagram

\section{Tampilan Sistem}

Pada tampilan sistem untuk aktivitas login, pegawai dan masyarakat memiliki tampilan login yang berbeda.

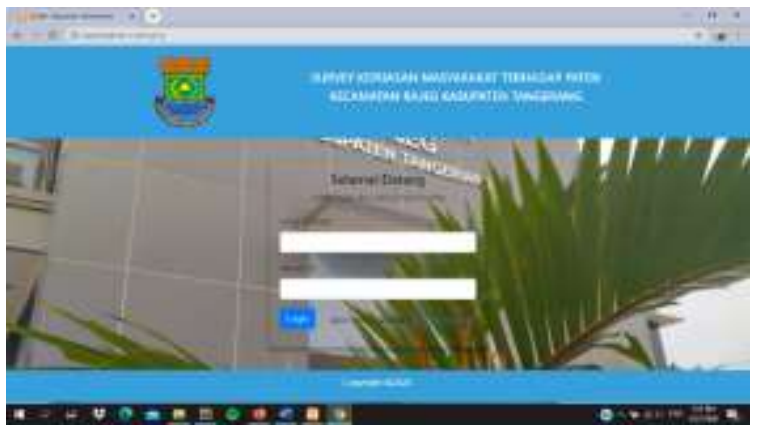

Gambar 5. Tampilan Login Masyarakat 

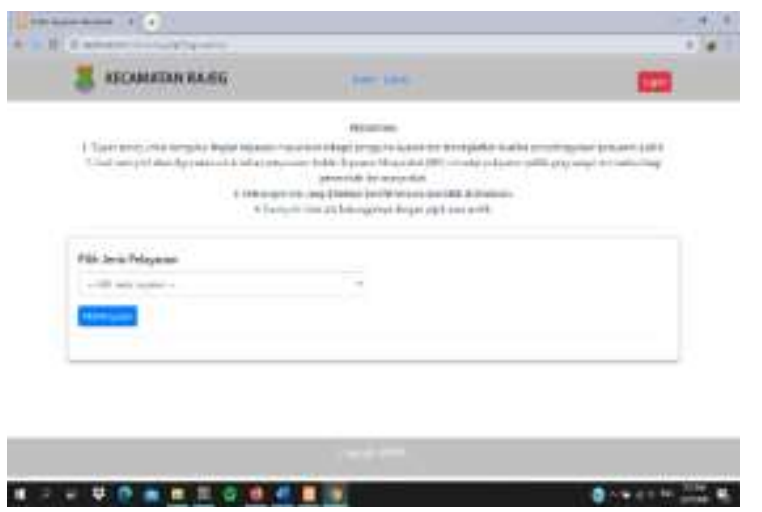

Gambar 6. Tampilan Form Survey

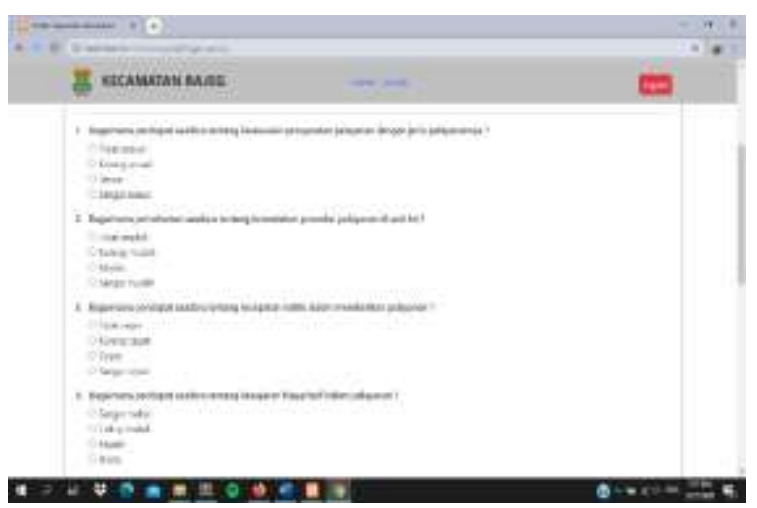

Gambar 7. Tampilan Form Pertanyaan

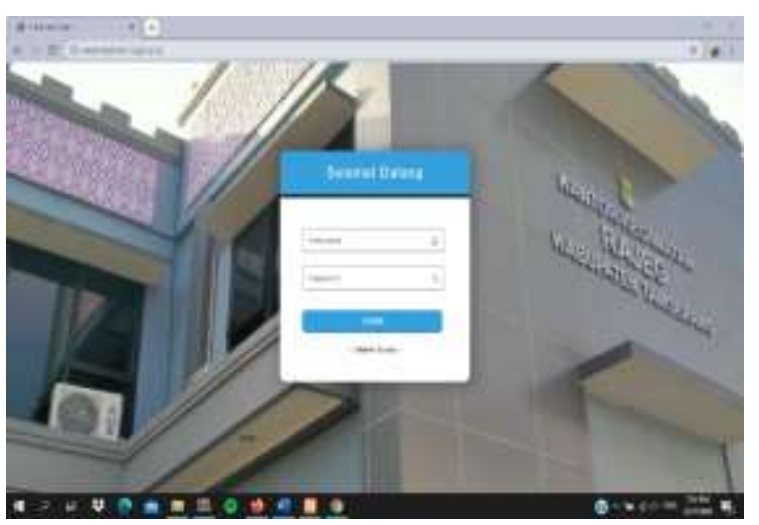

Gambar 8. Tampilan Login Pegawai

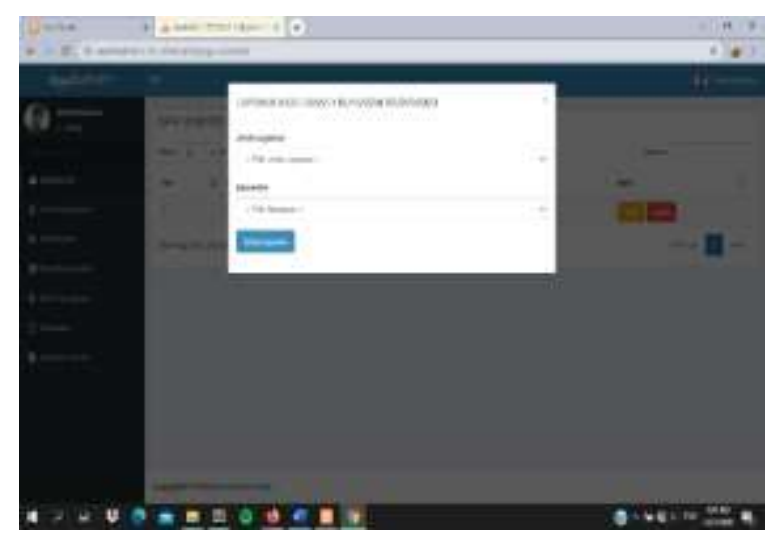

Gambar 9. Tampilan Laporan Survey

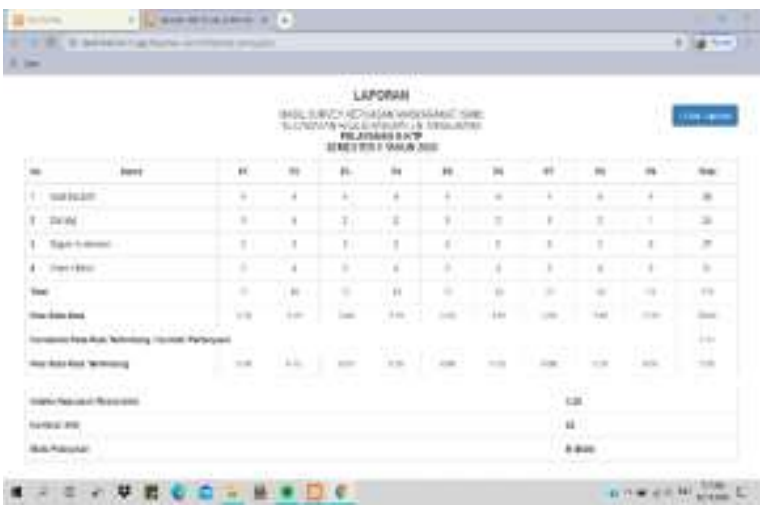

Gambar 10. Tampilan Review Laporan

\section{Pengujian Sistem}

Pengujian sistem menggunakan metode pengujian black box dan telah menghasilkan sebuah laporan pengujian sistem sebagaimana tabel 1 berikut ini:

Tabel 1. Pengujian Black Box

\begin{tabular}{|c|l|c|}
\hline No. & \multicolumn{1}{|c|}{ Proses } & Hasil \\
\hline 1. & Mengisi Password dan Email & Valid \\
\hline 2. & Klik Menu Survey & Valid \\
\hline 3. & $\begin{array}{l}\text { Pilih Jenis Pelayanan Pada } \\
\text { Menu Survey }\end{array}$ & Valid \\
\hline 4. & Mengisi Form Pertanyaan & Valid \\
\hline 5. & $\begin{array}{l}\text { Mengisi Dialog Kritik dan } \\
\text { Saran }\end{array}$ & Valid \\
\hline 6. & Pilih “Ok" Pada Pesan Dialog & Valid \\
\hline 7. & Pilih Logout & Valid \\
\hline
\end{tabular}

\section{KESIMPULAN}

Berdasarkan uraian yang telah dibahas sebelumnya, beberapa kesimpulan mengenai perancangan sistem informasi indeks kepuasan masyarakat terhadap pelayanan administrasi terpadu kecamatan pada kecamatan rajeg:

- Proses dari sistem Indeks Kepuasan Masyarakat Terhadap Pelayanan Terpadu Kecamatan yang berjalan saat ini menggunakan sistem konvensional dengan proses pembuatan kuesioner menggunakan Microsoft Word berikutnya form kuesioner di print-out dengan jumlah sesuai dengan keperluan survey dan diberikan kepada JIKA $\mid 6$ 
masyarakat untuk mengisi form. Lalu form dikumpulkan kembali oleh petugas untuk dilakukan perhitungan hasil survey menggunakan Microsoft Excel dengan format perhitungan sesuai dengan Keputusan Menteri Pemberdayaan Aparatur Negara Nomor KEP25/M.PAN/2/2004 untuk perhitungan data indeks kepuasan masyarakat.

- Perancangan dari website sistem informasi kepuasan masyarakat dibuat menggunakan tahap pengembangan sistem System Development Life Cycle (SDLC) dengan model Waterfall. Tahap penggambaran sistem menggunakan pendekatan analisis berorientasi objek dengan UML (Unified Model Languange). Sistem yang dikembangkan berbasis web dengan menggunakan bahasa pemrograman $P H P$ dan desain perancangan database. Berdasarkan dari hasil pengujian, dapat disimpulkan bahwa website sistem informasi kepuasan masyarakat pada Kecamatan Rajeg diterima oleh pihak user kecamatan. Sistem ini juga mudah digunakan oleh masyarakat dan bisa memberikan penilaian langsung baik dalam bentuk kritikan maupun saran dan dapat diterapkan untuk membantu Kantor Kecamatan Rajeg dalam mengukur Indeks Kepuasan Masyarakat.

\section{REFERENSI}

Alim. (2013). Step by Step Desain Proyek Menggunakan UML. Yogyakarta: Andi Offset.

James, A. O'Brien \& George, M. M. (2014). Sistem Informasi Manajemen. Jakarta: Salemba Empat.

Keputusan Menteri Pendayagunaan Aparatur Negara Nomor: KEP/25/M.PAN/2/2004 tentang Pedoman Umum Penyusunan Indeks Kepuasan Masyarakat.
Murad, dkk., 2013, Aplikasi Intelligence Website Untuk Penunjang Laporan PAUD Pada Himpaudi Kota Tangerang, Jurnal CCIT, Vol. 7 No. 1, September 2013.

Peraturan Bupati Tangerang Nomor 5 Tahun 2016 tentang Penyelenggaraan PATEN Di Kabupaten Tangerang.

Peraturan Menteri Dalam Negeri Nomor 4 Tahun 2010 tentang Pedoman Pelayanan Administrasi Terpadu Kecamatan (PATEN).

Rainer and Cegielski. (2011). Introduction to Information Systems. USA: Wiley.

Rosa, A. S. dan Shalahuddin, M. (2014). Rekayasa Perangkat Lunak Terstruktur Dan Berorientasi Obyek. Bandung: Informatika.

Vidia, D., dkk., 2013, Analisis Dan Perancangan Sistem Informasi Rawat Jalan Di Rumah Sakit Hewan Universitas Airlangga Surabaya Dengan Metode Berorientasi Objek, Skripsi, Universitas Airlangga, Surabaya.

Wijayanto, T., dkk., 2013, Analisis Dan Perancangan Sistem Informasi Pemesanan Dan Penjualan Barang Dengan Metode Berorientasi Objek Di U.D. Aneka Jaya Surabaya, Skripsi, Universitas Airlangga, Surabaya.

Yasin, V. (2012). Rekayasa Perangkat Lunak Berorientasi Objek. Jakarta: Mitra Wacana Media. 